\title{
Fermentasi Etanol dengan Bahan Baku Produk Sakarifikasi Singkong oleh Aspergillus niger dengan Menggunakan Isolat Saccharomyces spp. (NKB dan NKC)
}

\author{
TITIN HERAWATI ${ }^{1}$, THERESIA TRI SUHARNI ${ }^{1}$ \\ ${ }^{1}$ Fakultas Biologi, Universitas Gadjah Mada \\ J1. Teknika Selatan Sekip Utara Sleman Yogyakarta 55281 \\ email : eraw_tihee@yahoo.com
}

\begin{abstract}
Nowdays the production of petroleum energy resource decreases in every years. Ethanol is one of renewable source of energy, it can substitution of fosil fuel. Ethanol can be produced from fermentation by Saccharomyces. The raw material of ethanol fermentation is carbohydrate rich organic. Cassava is one of efisien based material for ethanol fermentation because of its attainable price and availability. The objectives of this study were to isolation yeast from coconut neera, and use the isolate as microbial etanol fermentation from cassava.

The research was started with isolating yeast from coconut neera, and then how to identified the yeast isolates by morphological and physiological characteristic. Then next process was saccharification the cassava by Aspergillus niger. Product of saccharification added by molasses to obtain $10 \%$ and $15 \%$ reducing sugar content and subjected for ethanol fermentation. The product of fermentation was analysed for the ethanol concentration by the conway microdiffuse and GCMS methode, Reducing sugar concentration was determined by DNS methode, total yeast was determined by spectroscopy methode and $\mathrm{pH}$ was determined by $\mathrm{pH}$ meter.

The result showed that the isolation from coconut neera get 4 yeast isolate Saccharomyces spp. namely NKA, NKB, NKC, and NKD. The NKB and NKC isolates were choosen as candidate being used for ethanol fermentation process. The process saccharification produced $8,43 \%$ of reducing sugar. The result of ethanol fermentation process from the product saccharification of cassava and molasse mixture with content $10 \%$ of reducing sugar were: NKB 4,19\% and NKC 5,19\%. Whereas the result ethanol fermentation from the product saccharification of cassava and molasse mixture with content $15 \%$ of reducing sugar were: NKB 6,75\% and NKC 6,34 \%.

Based on this study, it capable concluded that mixed of the product saccharification process by cassava and molasse can be used as raw material fermentation process of ethanol by Saccharomyces spp. isolate NKB and NKC which are to isolate from coconut neera.
\end{abstract}

Keywords: cassava, ethanol fermentation, molasses, saccharification, Saccharomyces spp.

\section{PENDAHULUAN}

Makin menipisnya cadangan minyak bumi dunia dari tahun ke tahun menyebabkan harga kerosin terus naik. Jalur distribusi dalam negeri yang tidak merata juga menjadi kendala lain ketersediaan kerosin bagi masyarakat daerah terpencil. Disamping itu, efek lingkungan pembakaran hidrokarbon telah membangkitkan kesadaran moral untuk pengembangan teknologi bahan bakar baru, misalnya etanol (Sugiyono, 1995). Etanol merupakan salah satu sumber energi terbaharui yang telah digunakan sejak zaman purba untuk bahan bakar lampu dan untuk memasak. Etanol memiliki kelebihan dibandingkan dengan bahan bakar fosil. Etanol mengandung $35 \%$ oksigen sehingga dapat meningkatkan efisisensi pembakaran. Etanol juga ramah lingkungan karena emisi gas buangnya rendah kadar $\mathrm{CO}, \mathrm{NO}_{\mathrm{x}}$, gas rumah kaca seperti $\mathrm{CO}_{2}$, serta logam berat dan senyawa karsinogenik. Etanol mudah terurai dan aman karena tidak mencemari air. (Hidayat, 2006). Hanya saja selama masa keemasan bahan bakar fosil dari perang dunia kedua hingga tahun 1980, peran bahan bakar berbasis biomassa tergantikan karena tidak didukung oleh pengembangan kebijakan teknologi dan politik (Soerowidjaja, 2003). 
Fermentasi etanol umumnya dilakukan oleh beberapa golongan khamir Saccharomyces, Kluyveromyces dan Candida serta beberapa golongan bakteri Zymomonas. Namun fermentasi etanol oleh khamir dari golongan Saccharomyces lebih umum digunakan, karena khamir ini mampu memproduksi enzim yang aktif dalam perubahan glukosa menjadi etanol (Becker and Eckhard, 2003). Beberapa khamir dapat diisolasi dari nira kelapa karena kandungan gula dalam nira kelapa berkisar 7,5$20 \%$ yang memungkinkan mikrobia untuk melakukan fermentasi alkohol secara spontan (Borse, et al., 2006).

Bahan baku fermentasi etanol berupa bahan organik kaya karbohidrat seperti gula tebu, nira, beras, singkong, bahkan limbah pertanian dan kehutanan dengan kadar selulosa tinggi. Singkong merupakan salah satu bahan baku fermentasi etanol yang efisien karena murah dan mudah didapat. Fermentasi berbahan dasar karbohidrat akan menghasilkan etanol, laktat, propionat, format, butirat, succinate, caproate, asetat, n-butanol, 2,3 butanadiol, aceton, 2-propanol, karbondioksida dan molekul hidrogen. Oleh karena itu fermentasi diklasifikasikan menjadi fermentasi etanol, fermentasi asam laktat, fermentasi asam propionik, fermentasi asam formik, fermentasi asam butyrik, fermentasi asam asetat (Hans, 1993).

Berdasarkan latar belakang tersebut, isolasi khamir dari nira kelapa dapat dilakukan dan dapat digunakan sebagai mikrobia pemfermentasi etanol dari bahan singkong. Peluang ini akan memberikan solusi bagi masyarakat untuk mendapatkan isolat khamir dari bahan alami dan cara memproduksi etanol dari bahan singkong serta menjadikannya sebagai alternatif dalam menghadapi krisis energi. Oleh karena itu penelitian mengenai "Fermentasi Etanol Berbahan Baku Produk Sakarifikasi Singkong oleh Aspergillus niger dengan Menggunakan Isolat Saccharomyces spp. " penting dilakukan.

\section{METODE}

Isolasi Khamir dari Nira kelapa. Isolasi khamir dari nira kelapa dilakukan dengan melalui kultur diperkaya yaitu dengan menginokulasikan $3 \mathrm{ml}$ nira kelapa ke dalam 30 $\mathrm{ml}$ media diperkaya (enrichment), diinkubasi selama 24 jam pada temperatur $30^{\circ} \mathrm{C}$. Setelah 24 jam, $1 \mathrm{ml}$ kultur cair ditanam secara taburan ke dalam petridish steril dengan medium YME agar, diinkubasi pada suhu kamar selama 48 jam (Vongsuwanlet et.al., 1981). Purifikasi dilakukan dengan goresan pada petridish steril dalam medium YME agar untuk mendapatkan koloni sel tunggal (single cell colony) (Singleton and Sainsbury, 1981).

Identifikasi Isolat Khamir. Identifikasi dilakukan dengan pengamatan morfologi dan pengujian sifat fisiologis.

Preparasi bahan fermentasi dan proses sakarifikasi bahan. Pada tahap ini dilakukan preparasi sampel singkong sebagai bahan baku fermentasi. Singkong yang diperoleh dari pasar Kranggan sebanyak $\pm 1500 \mathrm{mg}$ dipotong kecilkecil dan dibuat bubur dengan diblender dan penambahan air sampai volume $3000 \mathrm{ml}$. Selanjutnya dilakukan penyaringan dan diambil patinya. Sampel 60 gram pati singkong dan ditambahkan medium Yeast ekstrak 2,5 gr; $\mathrm{KH}_{2} \mathrm{PO}_{4} \quad 0,5$ gr; $\mathrm{MgSO}_{4} \cdot 7 \mathrm{H}_{2} \mathrm{O} \quad 2,5 \mathrm{gr}$; $\mathrm{FeSO}_{4} \cdot 7 \mathrm{H}_{2} \mathrm{O} 0,025$ gr; $\mathrm{CaCl}_{2} \cdot 2 \mathrm{H}_{2} \mathrm{O} 0,075$ gr; dan air sampai volume $500 \mathrm{ml}$, bahan disterilisasi dengan autoclave $121^{\circ} \mathrm{C}, 1 \mathrm{~atm}$ selama 15 menit. kemudian diinokulasikan Aspergillus niger dan dilakukan inkubasi dengan suhu $30{ }^{\circ} \mathrm{C}$ selama \pm 7 hari dan pemutaran $150 \mathrm{rpm}$. Selanjutnya dilakukan penyaringan sebanyak 3 kali (penyaringan terakhir dengan Whatman no 1). Selanjutnya dilakukan pengukuran $\mathrm{pH}$ dan kadar gula reduksi.

Proses fermentasi etanol. Larutan hasil sakarifikasi dituang ke dalam botol sampel.Selanjutnya dilakukan penambahan molasse untuk mendapatkan kadar gula sampai $10 \%$ dan $15 \%$ (dengan perbandingan hasil sakarifikasi singkong: molasse yang sudah diencerkan 1:1), $\mathrm{KH}_{2} \mathrm{PO}_{4} 1 \mathrm{gr} / 1 ; \mathrm{MgSO}_{4} .7 \mathrm{H}_{2} \mathrm{O}$ 0,5 gr/l dan $\left(\mathrm{NH}_{4}\right)_{2} \mathrm{SO}_{4} 1 \mathrm{gr} / 1$, dengan $\mathrm{pH} 5$. Selanjutnya bahan disterilisasi dengan autoclave $121^{\circ} \mathrm{C}, 1 \mathrm{~atm}$ selama 15 menit. Selanjutnya difermentasikan pada kultur batch menggunakan isolat Khamir Saccharomyces.

Analisis berat kering singkong dan Kadar air singkong. Berat kering singkong ini 
diukur dengan meletakkan sampel singkong dalam botol timbang dan diletakkan dalam oven suhu $70^{\circ} \mathrm{C}$ sampai berat singkong konstan. Kadar air singkong dihitung berdasarkan prosentase berat kering singkong yang dihasilkan terhadap berat basah sampel.

Analisis gula reduksi. Analisis gula reduksi menggunakan metode DNS yaitu $1 \mathrm{ml}$ larutan standar maupun sampel masing-masing ditambahkan $1 \mathrm{ml} \mathrm{H}_{2} \mathrm{O}$ dan $3 \mathrm{ml}$ larutan DNS, digojog sampai homogen dan dimasukkan ke dalam waterbath selama 15 menit. Masingmasing tabung dipindahkan ke tabung Coleman dan diamati optical density dengan spektrofotometer $\lambda 540 \mathrm{~nm}$. Dan kemudian dianalisis kadar gula reduksinya.

Analisis kadar etanol. Analisis kadar etanol menggunakan metode Conway yaitu 1 $\mathrm{ml} \mathrm{K}_{2} \mathrm{CO}_{3}$ jenuh diletakkan pada bagian $\mathrm{B}, 1 \mathrm{ml}$ larutan kalium dikromat diletakkan pada bagian A, dan $1 \mathrm{ml}$ larutan alkohol standar atau sampel diletakkan pada bagian C. Alat Conway ditutup dan diinkubasi pada temperatur $30^{\circ} \mathrm{C}$ selama 2 jam. Larutan A diencerkan menjadi $10 \mathrm{cc}$, setelah itu diamati pada spektro i $480 \mathrm{~nm}$.

Analisis Hasil. Data penelitian berupa konsentrasi alkohol,dan gula reduksi pada variasi isolat khamir dianalisis menggunakan uji statistik $t$-Test berpasangan dengan aplikasi program komputer SPSS for Windows versi 12 .

\section{HASIL}

Isolasi dan Identifikasi Khamir dari Nira kelapa. Pada penelitian ini diperoleh 4 isolat yaitu NKA, NKB, NKC, NKD. Pemberian nama isolat tersebut berdasarkan asal isolat tersebut diperoleh yaitu dari nira kelapa dan aktivitasnya dalam memfermentasi gula menjadi etanol. Isolat-isolat tersebut diperoleh dari proses inokulasi nira kelapa ke dalam medium diperkaya yang mengandung $3 \%$ etanol. Hal ini bertujuan agar khamirkhamir yang mampu melakukan fermentasi etanol dan dapat bertahan hidup pada media yang mengandung etanol dapat tumbuh dan dapat diisolasi.

Isolat khamir yang diperoleh, terlihat sedang melakukan budding secara multilateral yang merupakan salah satu cara perbanyakan diri secara vegetatif dengan melakukan pertunasan di beberapa bagian permukaan sel induknya. Kebanyakan anggota dari khamir juga melakukan reproduksi secara seksual dengan pembentukan spora seksualnya. Golongan khamir Ascomycetes akan membentuk askospora, Saccharomyces merupakan salah satu golongan khamir Ascomycetes. Untuk memperoleh spora seksual pada khamir golongan Saccharomyces direkomendasikan menggunakan medium acetat agar (Walker, 1998).

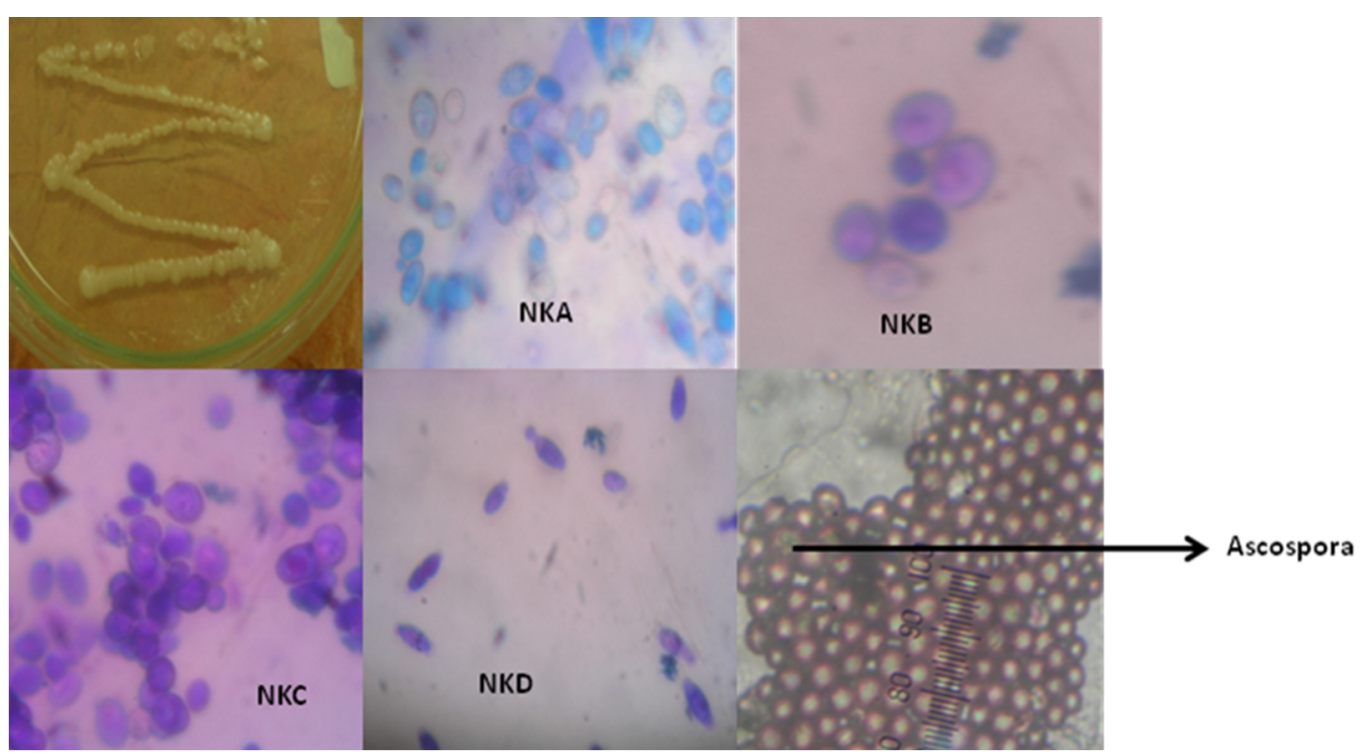

Gambar 1. Bentuk koloni, sel dan ascospora dari khamir isolat NKA, NKB, NKC, NKD hasil isolasi dari nira kelapa (Herawati,2008) 
Tabel 1. Karakter-karakter identifikasi khamir hasil isolasi dari nira kelapa

\begin{tabular}{lcccccc}
\hline \multirow{2}{*}{ Karakter yang diamati } & \multicolumn{5}{c}{ Isolat khamir } \\
\cline { 2 - 6 } & Saccharomyces & NKA & NKB & NKC & NKD \\
\hline 1. Hidrolisis Urea & - & - & - & - & - \\
\hline 2. Medium cair & & & & & \\
$\begin{array}{l}\text { a. pelicle } \\
\text { b. sedimen }\end{array}$ & - & - & - & - & - \\
\hline
\end{tabular}

3. Medium Padat

\begin{tabular}{|c|c|c|c|c|c|}
\hline $\begin{array}{l}\text { a. Profil } \\
\text { smooth }\end{array}$ & + & + & + & + & + \\
\hline b. Margin & & & & & \\
\hline Entire & + & + & + & + & + \\
\hline c. Warna & & & & & \\
\hline Krem & + & + & + & + & + \\
\hline
\end{tabular}

\begin{tabular}{cccccc}
\hline 4. Fermentasi & & & & & \\
\hline a. Glukosa & + & + & + & + & + \\
\hline b. Fruktosa & + & + & + & + & + \\
\hline c. Sukrosa & + & + & + & + & + \\
\hline d. Galactosa & v & + & + & + & + \\
\hline e. Lactosa & - & - & - & - & - \\
\hline f. Maltosa & v & - & - & - & - \\
\hline g. Raffinosa & + & + & + & + & + \\
\hline
\end{tabular}

5. Pertumbuhan dalam

\begin{tabular}{llllll} 
a. $5 \%$ Glukosa & + & + & + & + & + \\
\hline b. $50 \%$ Glukosa & + & + & + & + & + \\
\hline $\begin{array}{l}\text { 6. Pencairan Gelatin } \\
\text { 7. Pembentukan amyloid pada } \\
\text { medium starch }\end{array}$ & - & - & - & - & - \\
\hline
\end{tabular}

8. Asimilasi sumber karbon

\begin{tabular}{llllll} 
a. Glukosa & + & + & + & + & + \\
b. D-Xylosa & - & - & - & - & - \\
c. Sukrosa & v & - & - & - & - \\
\hline
\end{tabular}

9. Asimilasi sumber Nitrogen

\begin{tabular}{llllll} 
a. $(\mathrm{NH} 3) 2 \mathrm{SO} 4$ & - & - & - & - & - \\
b. $\mathrm{NaNO} 3$ & - & - & - & - & - \\
c. $\mathrm{KNO} 3$ & - & - & - & - & - \\
\hline
\end{tabular}

\begin{tabular}{llllllll}
\hline $\begin{array}{l}\text { 10. } \begin{array}{l}\text { Bentuk sel } \\
\text { vegetatif }\end{array} \\
\text { multilateral bud }\end{array}$ & & & & & & & \\
\hline
\end{tabular}

11. Bentuk sel spora (Reproduksi generatif)

\begin{tabular}{|c|c|c|c|c|c|}
\hline a. Bentuk Asci & & & & & \\
\hline Spheroidal & + & + & + & + & + \\
\hline \multicolumn{6}{|l|}{ b. Jumlah ascospora } \\
\hline $1-4$ & + & + & + & + & + \\
\hline \multicolumn{6}{|l|}{ c. Letak Asci } \\
\hline central & + & + & + & + & + \\
\hline \multicolumn{6}{|l|}{ d. Formasi asci } \\
\hline Unconjugated ascus & + & + & + & + & + \\
\hline Penghasilan etanol (\%) & & 0,69 & 0,79 & 0,83 & 0,61 \\
\hline
\end{tabular}


Fermentasi etanol berbahan baku campuran produk sakarifikasi singkong dan molasse. Sebelum singkong digunakan untuk proses fermentasi dilakukan terlebih dahulu proses sakarifikasi. Proses sakarifikasi ini bertujuan untuk mengubah pati yang terkandung dalam singkong menjadi gula reduksi (terutama glukosa) dengan bantuan enzym amiloglukosidase yang diproduksi oleh Aspergillus niger.

Tabel 2. Biomassa Aspergillus niger, kadar gula reduksi dan $\mathrm{pH}$ selama proses sakarifikasi singkong

\begin{tabular}{cccc}
\hline Waktu & $\begin{array}{c}\text { Biomassa } \\
\text { Aspergillus } \\
\text { niger }\end{array}$ & $\begin{array}{c}\text { Kadar } \\
\text { gula } \\
\text { reduksi }\end{array}$ & $\mathrm{pH}$ \\
\hline Hari 0 & $0,12 \mathrm{mg} / \mathrm{ml}$ & $0,11 \%$ & 5 \\
\hline Hari 2 & - & $0,4 \%$ & 5 \\
\hline Hari 4 & - & $2,85 \%$ & 5 \\
\hline Hari 6 & - & $8,29 \%$ & 4,5 \\
\hline Hari 7 & $17,5 \mathrm{mg} / \mathrm{ml}$ & $8,43 \%$ & 4,5 \\
\hline
\end{tabular}

Pada proses awal sakarifikasi sudah terdapat gula reduksi sebesar $0,11 \%$. Selanjutnya bubur pati singkong diinokulasi Aspergillus niger sebanyak $0,12 \mathrm{mg} / \mathrm{ml}$. Setelah 7 hari, proses sakarifikasi tersebut menghasilkan gula reduksi paling maksimal yaitu sebesar $8,43 \%$ dengan jumlah biomassa Aspergillus niger sebanyak $17,5 \mathrm{mg} / \mathrm{ml}$ (Tabel 2).

Untuk melakukan proses fermentasi harus mengetahui fase-fase pertumbuhan (fase lag, fase eksponensial, dan fase stationer) dari isolat khamir yang digunakan.

Isolat $\mathrm{NKB}$ dalam medium campuran produk sakarifikasi singkong + molasse $10 \%$ mulai mengalami fase eksponensial pada jam ke 32 sampai jam ke 56 (Gambar 3). Pada jam ke 56 merupakan waktu khamir mulai mengalami fase stationer, namun penghasilan etanol masih mengalami kenaikan. Pada akhir fermentasi yaitu jam ke 72 dengan jumlah khamir $4,02 \times 10^{9}$ dihasilkan etanol sebesar $4,28 \%$, sisa gula reduksi sebesar $0,44 \%$, dan $\mathrm{pH}$ 3,08 . Isolat $\mathrm{NKC}$ dalam medium campuran produk sakarifikasi singkong + molasse $10 \%$ mulai mengalami fase eksponensial pada jam ke 24 sampai jam ke 48 (Gambar 4).

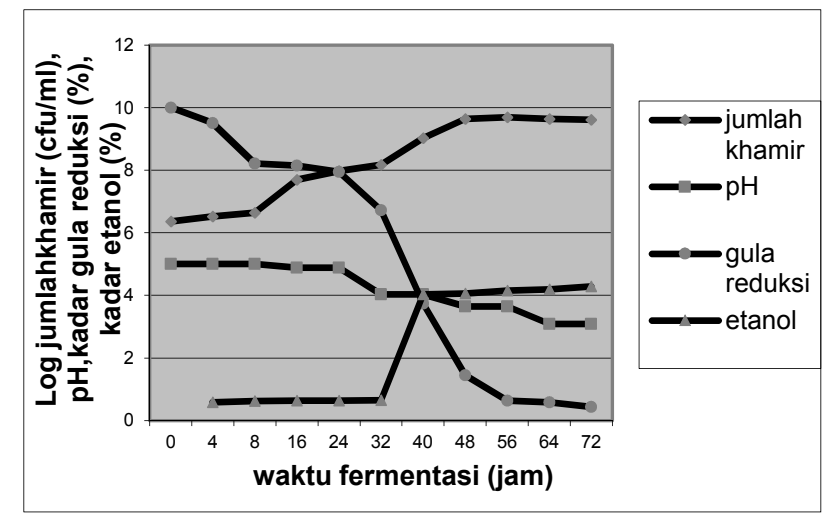

Gambar 3. Kurva pertumbuhan khamir isolat NKB pada medium yang mengandung $10 \%$ gula

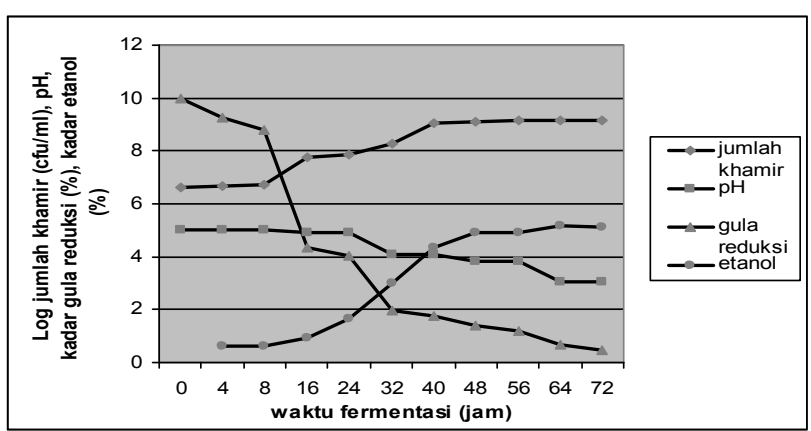

Gambar 4. Kurva pertumbuhan khamir isolat NKC pada medium yang mengandung $10 \%$ gula

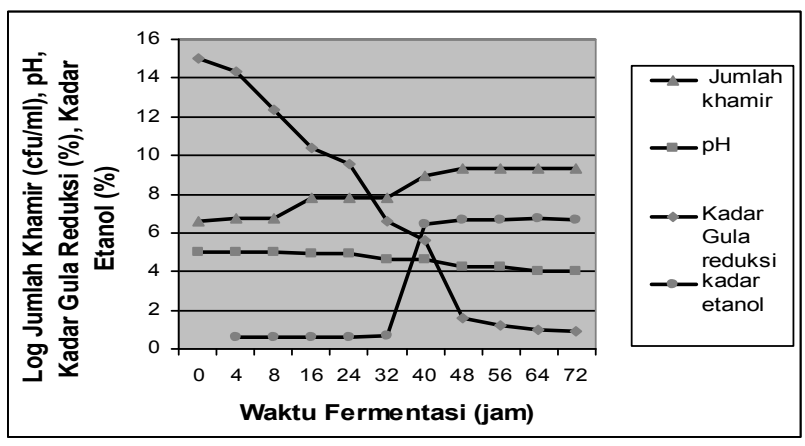

Gambar 5. Kurva pertumbuhan khamir isolat NKB pada medium yang mengandung $15 \%$ gula

Pada jam ke 48 merupakan waktu khamir mulai mengalami fase stationer, namun penghasilan etanol masih mengalami kenaikan. Pada akhir fermentasi yaitu jam ke 72 dengan jumlah khamir $1,52 \times 10^{9}$ dihasilkan etanol sebesar 5,12\%, sisa gula reduksi sebesar $0,48 \%$, dan $\mathrm{pH} 3,06$.

Isolat $\mathrm{NKB}$ dalam medium campuran produk sakarifikasi singkong+molasse 15\% mulai mengalami fase eksponensial pada jam 
ke 32 sampai jam ke 48 (Gambar 5). Pada jam ke 48 merupakan waktu khamir mulai mengalami fase stationer. Pada akhir fermentasi yaitu jam ke 72 dengan jumlah

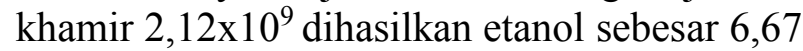
$\%$, sisa gula reduksi sebesar $0,89 \%$, dan $\mathrm{pH}$ 4,01 .

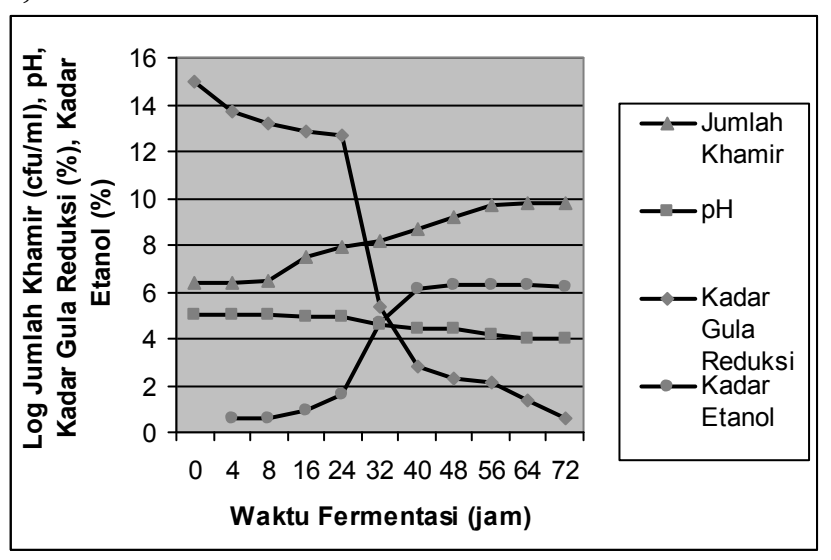

Gambar 6. Kurva pertumbuhan khamir isolat NKC pada medium yang mengandung $15 \%$ gula

Tabel 3. Kecepatan pertumbuhan spesifik $(\mu)$, Yield produk terhadap substrat $(\mathrm{Y} p / \mathrm{s})$ dan efisiensi pembentukan etanol saat fase eksponensial

\begin{tabular}{ccccc}
\hline \multirow{2}{*}{$\begin{array}{c}\text { Isolat } \\
\text { khamir }\end{array}$} & $\begin{array}{c}\text { Kadar } \\
\text { gula } \\
\text { dalam } \\
\text { medium }\end{array}$ & $\mu$ & $\mathrm{Y}$ p/s & $\begin{array}{c}\text { Efisiensi } \\
\text { pembentukan } \\
\text { etanol }\end{array}$ \\
\hline \multirow{2}{*}{ NKB } & $10 \%$ & 0,137 & 0,354 & $65,09 \%$ \\
\cline { 2 - 5 } & $15 \%$ & 0,127 & 0,397 & $69,41 \%$ \\
\hline NKC & $10 \%$ & 0,139 & 0,419 & $67,92 \%$ \\
\cline { 2 - 5 } & $15 \%$ & 0,137 & 0,390 & $65,67 \%$ \\
\hline
\end{tabular}

Isolat NKC dalam medium campuran produk sakarifikasi singkong+molasse 15\% mulai mengalami fase eksponensial pada jam ke 32 sampai jam ke 56 (Gambar 6). Pada jam ke 56 merupakan waktu khamir mulai mengalami fase stationer, namun penghasilan etanol masih mengalami kenaikan. Pada akhir fermentasi yaitu jam ke 72 dengan jumlah khamir 5,89x $10^{9}$ dihasilkan etanol sebesar 6,21 $\%$, sisa gula reduksi sebesar $0,61 \%$, dan $\mathrm{pH}$ 4,03 .
Tabel 4. Hasil GCMS produk fermentasi etanol pada jam ke 64

\begin{tabular}{|c|c|c|c|}
\hline $\begin{array}{l}\text { Isolat } \\
\text { Khamir }\end{array}$ & $\begin{array}{l}\text { Kadar } \\
\text { gula } \\
\text { dalam } \\
\text { medium }\end{array}$ & $\begin{array}{c}\text { Senyawa yang } \\
\text { terdeteksi }\end{array}$ & $\begin{array}{c}\text { Kadar } \\
\text { / Area } \\
(\%)\end{array}$ \\
\hline \multirow{5}{*}{ NKB } & \multirow{5}{*}{$10 \%$} & $\begin{array}{l}\text { 1. Mono } \\
\text { fluoroacetylene }\end{array}$ & 0,78 \\
\hline & & 2. Acetone & 9,03 \\
\hline & & 3. Etanol (1) & 80,77 \\
\hline & & $\begin{array}{l}\text { 4. 7-Hydroxy-7- } \\
\text { Phenyl-3,9- } \\
\text { diisoprophyl- } \\
\text { 2,10- } \\
\text { dioxadispiro } \\
\text { (3.3.3.1) } \\
\text { dodecan-1,11- } \\
\text { dione }\end{array}$ & 0,71 \\
\hline & & 5. Etanol (2) & 8,71 \\
\hline \multirow{3}{*}{ NKB } & \multirow{3}{*}{$15 \%$} & 1. Etanol (1) & 9,73 \\
\hline & & 2. Isopentanol & 1,01 \\
\hline & & 3. Asam asetat & 1,60 \\
\hline \multirow{4}{*}{$\mathrm{NKC}$} & \multirow{4}{*}{$10 \%$} & 1. Etanol (1) & 62,33 \\
\hline & & 2. Etanol (2) & 27,58 \\
\hline & & 3. Etanol (3) & 5,96 \\
\hline & & 4. Asam asetat & 4,13 \\
\hline \multirow{4}{*}{$\mathrm{NKC}$} & \multirow{4}{*}{$15 \%$} & 1. Etanol (1) & 91,69 \\
\hline & & 2. Etanol (2) & 5,78 \\
\hline & & 3. Isoamylol & 1,64 \\
\hline & & 4. Asam asetat & 0,89 \\
\hline
\end{tabular}

\section{PEMBAHASAN}

Isolat khamir yang diperoleh tidak memiliki kemampuan menghidrolisis urea (Tabel 1) , karakter ini digunakan untuk identifikasi awal khamir tersebut termasuk dalam golongan Ascomycetes, karena hanya khamir dari golongan Basidiomycetes yang memiliki kemampuan untuk menghidrolisis urea dengan ditandai terbentuknya warna kemerahan pada medium yang mengandung urea. Isolat khamir tersebut memiliki kemampuan untuk memfermentasikan glukosa, sukrosa, fruktosa, galaktosa dan rafinnosa dengan ditandai adanya perubahan warna medium dari biru kehijauan menjadi kuning dan terbentuk gelembung udara pada tabung durham. Selain itu khamir tersebut juga 
memiliki kemampuan untuk mengasimilasi sumber karbon berupa glukosa, mampu tumbuh pada medium yang mengandung kadar glukosa $5 \%$ dan 50\%. Berdasarkan karakter-karakter yang diamati dalam identifikasi, khamir hasil isolasi dari nira kelapa ini termasuk dalam genus Saccharomyces.

Penggunaan gula reduksi selain untuk proses fermentasi juga digunakan untuk pemenuhan energi dalam perbanyakan sel. Dari Tabel 3 terlihat bahwa kecepatan pertumbuhan spesifik pada NKB lebih tinggi daripada NKC sehingga gula reduksi yang diubah menjadi etanol juga lebih kecil (dari nilai $\mathrm{Y}$ p/s dan efisiensi pembentukan etanol). Sedangkan isolat NKB bekerja lebih optimal dalam proses fermentasi pada medium campuran produk sakarifikasi singkong + molasse $15 \%$ daripada isolat NKC. Hal ini dikarenakan pada isolat NKC penggunaan gula reduksi selain untuk proses fermentasi juga digunakan untuk pemenuhan energi dalam perbanyakan sel.

Proses fermentasi etanol oleh isolat NKB dan NKC dalam medium campuran produk sakarifikasi singkong+molasse $10 \%$ dan $15 \%$ efektif pada jam ke 64, namun pada jam tersebut juga terjadi penurunan nilai $\mathrm{pH}$ ke arah asam, mulai terbentuk asam organik lain selain produk etanol. Oleh karena itu hasil fermentasi etanol pada jam ke 64 selanjutnya diuji dengan GCMS (Tabel 4). Produk akhir selain etanol tersebut akan mempengaruhi kemampuan khamir dalam proses fermentasi etanol sehingga kadar etanol yang dihasilkan tidak maksimal (Ingledew, 2006).

Menurut Prescott and Dunn (1959) produk akhir selain etanol atau sering disebut sebagai fusel oil akan ikut terbentuk dalam proses fermentasi, antara lain berupa campuran amyl dan isoamyl alkohol, isobutyl, propyl alkohol, produk asam, ester, dan aldehyd. Terbentuknya fussel oil dipengaruhi oleh jenis bahan dasar yang digunakan dan jenis mineral yang ditambahkan dalam proses fermentasi. Penambahan alkali $\left(\mathrm{NaHCO}_{3}, \mathrm{Na}_{2} \mathrm{HPO}_{4}\right)$ menyebabkan terbentunya formasi glyserol karena acetaldehyd mengalami dismutasi menjadi etanol dan asetat dan dikarenakan tidak berfungsinya aseptor hydrogen dalam proses fermentasi (Hans, 1993).
2 Glukosa $+\mathrm{H}_{2} \mathrm{O} \rightarrow$ etanol + acetat +2 Glyserol $+2 \mathrm{CO}_{2}$

Oleh karena itu untuk menghilangkan fussel oil dalam produk etanol hasil fermentasi, maka dilakukan proses destilasi.

\section{KESIMPULAN}

1. Empat isolat Saccharomyces sp. berhasil diisolasi dari nira kelapa. Dua diantara keempat isolat khamir tersebut digunakan untuk proses fermentasi etanol yaitu NKB dan NKC.

2. Proses sakarifikasi singkong menggunakan Aspergillus niger menghasilkan gula reduksi sebesar $8,43 \%$.

3. Proses fermentasi berbahan dasar campuran produk sakarifikasi singkong+molasse $10 \%$ pada jam ke 64 menghasilkan etanol: isolat NKB 4,19\%, NKC 5,19\%. Sedangkan pada medium campuran produk sakarifikasi singkong + molasse $\quad 15 \%$ menghasilkan etanol : isolat NKB 6,75\%, NKC 6,34\%

\section{DAFTAR PUSTAKA}

Becker J and Eckhard B. 2003. A Modified Saccharomyces cerevisiae Strain that Consumes L-Arabinose and Produces Ethanol. Applied and Environmental microbiology. http://journal.asm.org. Diakses 16 juni 2007.

Borse BB, Lingamallu JMR, Kulathooram R, Bashyam R. 2006. Chemical Composition of Volatiles from Coconut Sap (Neera) and Effect of Processing. http://www. sciencedirect.com. Diakses 5 Mei 2007.

Hans GS. 1993. General Microbiology $7^{\text {th }}$ ed. New York: Cambridge University Press. pp 290-299.

Hidayat D. 2006. Bensin dioplos Singkong. http://cdc.eng.ui.ac.id. Diakses 22 Maret 2006.

Ingledew WM. 2006. Improvement in Alcohol Technology Through Advancements in Fermentation Technology. http://www. journal.asm.org. Diakses 4 Oktober 2007.

Prescott SC and Dunn CG. 1959. Industrial Microbiology 3th ed. Japan: Mc Graw-Hill Book Company, Inc. pp 102-109. 
Skinner FA, Susan MP, and Davenport RR. 1980. Biology and Activities of Yeast. New York: Academic Press. pp 33-43, 103

Sugiyono A. 1995. Proses Hydrocarb untuk Biomassa dan Bahan Bakar Fosil. Prosiding Prospek Pengembangan Biomassa sebagai Sumber Energi di
Indonesia. Jakarta: INNERTAPIndonesia. hal 83-90.

Soerowidjaja TH. 2003. Kendala Pengembangan Bisnis Energi Biomassa dan Solusinya. Pusat Penelitian Material dan Energi Lembaga Penelitian ITB. Bandung: ITB. hal 1-5. 